\title{
Diario de Irak: A Just War or Just War?
}

\author{
William O. Deaver, Jr. ${ }^{1}$
}

This study examines Mario Vargas Llosa's trip to Iraq in 2003 and his conclusions regarding the rationales for the U. S.-led occupation. Vargas Llosa observes that the war was initiated under false pretenses, and that the Iraqi people are frustrated with the chaos and instability. Extremists who fear Western encroachment on Middle Eastern cultures, prefer to see war in Iraq rather than on their own soils. I use the theories of Marshall McLuhan, Sun Tzu, and Paul Virilio to illustrate the strategies involved in the war machine's success as well as the lie of democracy which is used to deceive people into believing that the war is just. According to Virilio, we are purchasing protection and security at the cost of our own freedoms, which have been eroded by the Homeland Security Act. [Article copies available for a fee from The Transformative Studies Institute. E-mail address: journal@transformativestudies.org Website: http://www.transformativestudies.org (C2009 by The Transformative Studies Institute. All rights reserved.]

KEYWORDS: Iraq, Sun Tzu, Paul Virilio, Marshall McLuhan, Mario Vargas Llosa, War, Democracy, Freedom, Deception.

In 2003, Mario Vargas Llosa, one of Latin America's preeminent novelists, journeyed for twelve days through Iraq to witness the impact on the Iraqi people of the U. S.-led invasion. Vargas Llosa reconsidered his

\footnotetext{
${ }^{1}$ William O. Deaver, Jr., Ph.D., is a professor of Spanish at Armstrong Atlantic State University in Savannah, Georgia. He has published numerous literary analyses on the works of Gabriel García Márquez, Roberto G. Fernández, Virgil Suárez, Elías Miguel Muñoz, Leopoldo Alas (Clarín), Pío Baroja, Miguel Piñero, Marcela del Río, Felipe Benítez Reyes, Julio Garmendia, as well as on film directed by Tomás Gutiérrez Alea, and the music of Rubén Blades. He holds a B. A. in English from the University of Virginia, a M.A. in Spanish from the University of Virginia, and a Ph.D. in Spanish from Florida State University. Address correspondence to: William O. Deaver, Jr., Department of Languages, Literature, and Philosophy, Armstrong Atlantic State University, 11935 Abercorn Street, Savannah, Georgia 31419-1997; tel: 912.344.2799; e-mail: bill.deaver@armstrong.edu.
} 